\title{
Non-appearance before the International Court of Justice and the Role and Function of Judges ad hoc
}

\author{
Andres Sarmiento Lamus \\ Ph.D. candidate, Leiden University, The Netherlands; Professor of Public \\ International Law, Universidad Sergio Arboleda, Colombia; Member, \\ Colombian Academy of International Law \\ andres.sarmiento@usa.edu.co \\ Walter Arévalo Ramírez \\ Ph.D. candidate; Professor of Public International Law, Universidad del Rosario, \\ Colombia; Member, Colombian Academy of International Law \\ walter.arevalo@urosario.edu.co
}

\begin{abstract}
An endless discussion has taken place regarding the role and function of judges ad hoc in contemporary international adjudication. In this regard, doctrine has been important through its ample contribution to the understanding of the institution of the judge $a d$ hoc and its role and function. In fact, from these contributions it is possible to affirm the relevance of the judge ad hoc in contemporary international adjudication. Nonetheless, all these aspects have been analysed having in mind cases where both parties take part in the proceedings. Consequently, a question arises as to what is the role and function of a judge ad hoc when the appointing state fails to defend its case. This article seeks therefore to analyse the role and function of judges ad hoc in cases of partial non-appearance before the International Court of Justice.
\end{abstract}

\section{Keywords}

Judges ad hoc - non-appearance - failure to defend its case - role and function of judges ad hoc 


\section{Introduction}

An endless discussion has taken place regarding the role and function of judges ad hoc in contemporary international adjudication. On the one hand, it has been argued that the participation of these judges should not be allowed. They are often considered as representatives of the appointing state as they normally cast their vote in favour of the appointing state. ${ }^{1}$ In consequence, it is believed that their presence on the bench does not serve any purpose ${ }^{2}$ and compromises their qualifications of independence and impartiality. On the other hand, the appointment of a judge ad hoc is considered as a prerogative for states, and without which they would hardly accept the jurisdiction of an international court or tribunal. Hence, and despite opposition to this institution, it has emerged in international adjudication with the firm intention of being here to stay.

Doctrine has thus been fundamental in the determination of the role and function of judges ad hoc. It is believed that one of the most authoritative pronouncements in this regard was made by Sir Elihu Lauterpacht, in the separate opinion appended to the second request for the indication of provisional measures, in the case concerning the Application of the Convention on the Prevention and Punishment of the Crime of Genocide, ${ }^{3}$ where he acted as judge ad hoc for Bosnia-Herzegovina. In his view,

[the judge ad hoc] has, I believe, the special obligation to endeavour to ensure that, so far as is reasonable, every relevant argument in favour of the party that has appointed him has been fully appreciated in the course of collegial consideration and, ultimately, is reflected - though not necessarily accepted - in any separate or dissenting opinion that he may write. ${ }^{4}$

1 Nicolas Valticos, "L'evolution de la notion de juge ad hoc", 50 Revue Hellénique du Droit International (1977), 1, 9; Pieter Kooijmans, "Article 31", in Andreas Zimmermann et al. (eds.), The Statute of the International Court of Justice: A Commentary, (2nd edition, 2012), 530, 533.

2 Currim Chagla, "Rule of Law and the International Court of Justice", 54 American Society of International Law Proceedings (1960), 237, 242.

3 Application of the Convention on the Prevention and Punishment of the Crime of Genocide (Bosnia and Herzegovina v. Yugoslavia (Serbia and Montenegro)), Further Request for the Indication of Provisional Measures, Order, I.C.J. Reports 1993, p. 325.

4 Ibid., (Separate Opinion, Judge ad hoc Lauterpacht), p. 409, para. 6. 
Nevertheless, as will be addressed in more detail below, this and other assessments made with regard to the role and function of judges ad hoc are based on the participation in the proceedings of both parties to the dispute.

The non-appearance of one of the parties poses several distinctive characteristics when compared to proceedings where both parties appear before the court or tribunal. Notably, the non-appearing state does not submit any formal arguments whatsoever and, thus, in consequence, does not submit any formal submissions. ${ }^{5}$ Similarly, in the context of the International Court of Justice (hereinafter referred to as "the Court"), in order to make a decision it should ensure that the appearing state's claim is well founded in fact and law.

In this order of ideas, and in the light of these distinctive characteristics, a question arises as to what are the role and function of judges ad hoc in cases of non-appearance. To put it another way, the question that arises refers to whether the role and function of judges ad hoc are still the same, when the appointing state is absent from the proceedings. It is to be noted that this question is only relevant in situations where the non-appearing state fails to defend its case, after having appointed a judge ad hoc. So far, the Corfu Channel case is the only instance where a state party to proceedings has decided to stop appearing before the Court to defend its case, after having appointed Bohuslav Ečer as judge ad hoc.

Similarly, the question that this article attempts to address does not have an exclusive academic purpose. This is a situation likely to occur in future proceedings, especially in cases where states consider that their sovereign rights are at stake. For instance, the possibility that a state that has already appointed a judge $a d$ hoc might fail to defend its case was until recently latent, in the ongoing case concerning Question of the Delimitation of the Continental Shelf between Nicaragua and Colombia beyond 200 Nautical Miles from the Nicaraguan Coast between Nicaragua and Colombia.

In its Judgment of 17 March 2016, on the preliminary objections presented by Colombia in the Alleged Violations of Sovereign Rights and Maritime Spaces in the Caribbean Sea (Nicaragua v. Colombia) case, the Court rejected all of Colombia's objections to the jurisdiction of the Court. ${ }^{6}$ In consequence, it decided that it has jurisdiction to entertain both cases between Colombia and Nicaragua on the merits.

Some hours after the Court concluded the reading of both judgments, President Juan Manuel of Colombia stated that his country

5 Shabtai Rosenne, The World Court: What It Is and How it Works (2003), 79.

6 Alleged Violations of Sovereign Rights and Maritime Spaces in the Caribbean Sea (Nicaragua v. Colombia), Preliminary Objections, Judgment, I.C.J. Reports 2016, p. 32, paras. 77-79. 
will not keep appearing before the ICJ ... the Hague Court has incurred in substantial incongruences [in the case concerning Question of Delimitation of the Continental Shelf between Nicaragua and Colombia beyond 200 Nautical Miles from the Nicaraguan Coast], did not respect its decision of 2012 and disregarded its own Statute by re-opening a case already settled and pretends to make applicable a treaty [the United Nations Convention on the Law of the Sea] to which we are not a party ... Colombia respects the rule of law, but also expects the respect for the rule of law and that has not happened today.

During the proceedings in both cases, Nicaragua and Colombia exercised their right conferred upon them by Article 31, paragraph 3, of the Statute of the Court and therefore appointed judges ad hoc. Whereas Colombia appointed Charles Brower, Nicaragua chose the former judge of the Court, Leonid Skotnikov. Colombia decided at the last minute (but within the time-limit fixed by the Court) to file its counter-memorial. Hence, and despite that it is not so far possible to speak of a failure to defend its case, ${ }^{7}$ this instance constitutes a good example of the practical relevance of the question that this article attempts to analyse.

Similarly, and despite its being in the context of an advisory proceeding, the possibility that a state that had already appointed a judge ad hoc might fail to defend its case is also latent in the recent request for an advisory opinion concerning the Legal consequences of the separation of the Chagos Archipelago from Mauritius in 1965. Should Judge Greenwood eventually not be able to participate, ${ }^{8}$ and the United Kingdom decides to appoint a judge ad hoc (having the Court decide that the request refers to a legal question actually pending between two states), ${ }^{9}$ it may be possible that it will decide later on to

7 In this case, as well as in all other on-going cases before the Court where the parties have submitted their written pleadings, the non-appearance of one of the parties to the dispute still is a possibility. As noted by Bowett, Article 53 of the Statute of the Court is also applicable when a party fails to defend its case during oral proceedings. Cf. Derek W. Bowett, "Contemporary Developments in Legal Techniques in the Settlement of Disputes", 180 Collected Courses of the Hague Academy of International Law (1984), 169, 205-206.

8 Dapo Akande and Antonio Tzanakopoulos, "Composition of the Bench in ICJ Advisory Proceedings: Implications for the Chagos Islands case", EJIL: Talk! Blog of the European Journal of International Law, published on 10 July 2017, available at www.ejiltalk.org/compo sition-of-the-bench-in-icj-advisory-proceedings-implications-for-the-chagos-islands-case/ (accessed on 7 November 2017).

9 Western Sahara (Request for Advisory Opinion), Order, I.C.J. Reports 1975, pp. 7-8. 
fail to defend its case. This instance may also pose the question as to what the role and function of the judge ad hoc would be.

With a view toward addressing the said question, this article will proceed as follows. An overview and presentation of the procedural and substantive aspects of non-appearance at the Court will be provided in Section 2. This overview will be limited to those aspects that are relevant for the subsequent ascertainment of the role and function of judges ad hoc. In Section 3, this article will present the role and function of judges ad hoc as they have been currently envisaged in the doctrine. An analysis concerning what are to be considered the role and function of judges ad hoc, when the appointing state fails to defend its case, will be conducted in Section 4. Finally, Section 5 will present a conclusion with respect to the specific topic of this article.

\section{2 \\ Non-appearance in the Statute and the Practice of the Court}

Article 53 of the Statute of the Court regulates the manner in which the Court should act when one of the parties does not appear before it or fails to defend its case. It does not confer a right on states for non-appearance before the Court, ${ }^{10}$ or impose any sanction whatsoever as a consequence arising from a decision of this kind by a state. Hence, whereas the first paragraph of this provision consecrates a right for the appearing party to call upon the Court to decide in favour of its claim, the second paragraph imposes an obligation on the Court to satisfy itself that (along with having jurisdiction) the said claims are well founded in fact and law. ${ }^{11}$ In consequence, the Court only seems to be obliged to consider the submissions of the party which appears, without it being necessary to examine the accuracy of those submissions in all of their details. ${ }^{12}$

Nevertheless, as the Court has put it in the most recent cases where the respondent state has failed to defend its case,

10 The Institut de Droit International indicated in Article 1 of its Resolution on NonAppearance before the International Court of Justice, adopted in 1991, that "[e]ach State entitled to appear before the Court and with respect to which the Court is seized of a case is ... a party to the proceedings." Cf. Institut de Droit International, "Non-Appearance before the International Court of Justice", 64 Annuaire de l'Institut de Droit International (1991), 276.

11 James D. Fry, "Non-Participation in the International Court of Justice Revisited: Change or Plus Ça Change?", 45 Columbia Journal of Transnational Law (2010), 45.

12 The Corfu Channel Case, Assessment of the Amount of Compensation due from the People's Republic of Albania to the United Kingdom of Great Britain and Northern Ireland, Judgment, I.C.J. Reports 1949, p. 244. 
[f] or the purposes of deciding whether the claim is well founded in law, the principle jura novit curia signifies that the Court is not solely dependent on the argument of the parties before it with respect to the applicable law ... [it is bound] to consider on its own initiative all rules of international law which may be relevant for the settlement of the dispute ... the law lies within the judicial knowledge of the Court. ${ }^{13}$

The Court should therefore not take into account only the arguments advanced by the party which appears. Being its duty to satisfy itself that it is in possession of all of the available information, ${ }^{14}$ it can also take into account any other relevant rules of international law that it considers necessary and the arguments advanced by the non-appearing state throughout previous phases of the proceedings in which that state presented pleadings. ${ }^{15}$ Similarly, the Court may also draw attention to irregular documents brought to its attention by the non-appearing party. ${ }^{16}$ When analysing these irregular documents, however, the Court should ensure that the non-appearing state is not benefited by its absence. Hence, the weight to be given to these documents depends on what is required to secure the proper administration of justice and the opportunity for each party to comment on its opponent's contentions. ${ }^{17}$

\section{$3 \quad$ Role and Function of Judges ad hoc}

When the Committee of Jurists (entrusted with the task of drafting the Statute of the Permanent Court of International Justice) discussed the issue of judges ad hoc, it stressed the importance of giving the parties the possibility to appoint a representative, in order to protect their interests and to enable the Permanent Court of International Justice to understand certain questions requiring highly specialised knowledge due to the differences between legal

\footnotetext{
13 Military and Paramilitary Activities in and against Nicaragua (Nicaragua v. United States of America), Merits, Judgment, I.C.J. Reports 1986, p. 14, para. 29.

14 Nuclear Tests (Australia v. France), Judgment, I.C.J. Reports 1974, p. 263, para. 31.

15 Military and Paramilitary Activities in and against Nicaragua, supra note 13, p. 14, para. 28.

16 Fisheries Jurisdiction (United Kingdom v. Iceland), Merits, Judgment, I.C.J. Reports 1974, p. 9, para. 17; Fisheries Jurisdiction (Federal Republic of Germany v. Iceland), Merits, Judgment, I.C.J. Reports 1974, p. 18, para. 181; Aegean Sea Continental Shelf (Greece v. Turkey), Preliminary Objections, Judgment, I.C.J. Reports 1978, p. 7, para. 14.

17 Military and Paramilitary Activities in and against Nicaragua, supra note 13, pp. 25-26, para. 31 .
} 
systems. ${ }^{18}$ Likewise, this would legitimate the adjudication process and the acceptance of the judgment by the parties to the dispute. ${ }^{19}$ The appointment of the judge ad hoc was therefore considered a prerogative of states parties to the proceedings.

Much has been written in the academic literature regarding judges ad hoc. An important number of these references are related to a discussion regarding whether a role and function exist for these judges. On the one hand, it has been noted that judges ad hoc are an echo of the old arbitral justice system, ${ }^{20}$ so that they do not serve any purpose whatsoever, ${ }^{21}$ as they tend to vote in support of the appointing state position ${ }^{22}$ and therefore their independence and impartiality seem to be compromised. ${ }^{23}$

On the other hand, it has also been noted that judges ad hoc do not always support the positions of the states that have appointed them. ${ }^{24}$ The fact that there is often a concordance between the position of the state and the judge ad hoc does not mean, however, that they constitute advocates or counsel for that state. ${ }^{25}$ What tends to occur is that this concordance of views is usually a precondition for accepting to be a judge $a d$ hoc. ${ }^{26}$ As it was put in a recent academic article, judges ad hoc

18 Permanent Court of International Justice: Advisory Committee of Jurists, Procès-Verbaux of the Proceedings of the Committee June 16th-July 24th, 1920 with annexes (1920), 528-529. See, e.g., "Enrica Lexie" Incident (Italy v. India), Request for the prescription of provisional measures, Order, ITLOS Reports 2015, (Judge ad hoc Francioni), pp. 4-5, paras. 10-15.

19 Ibid., at 536.

$20 \quad$ Robert Kolb, The International Court of Justice (2013), 119.

21 Ian Scobbie, "Une Heresie en Matiere Judiciaire'? The Role of the Judge ad hoc in the International Court", 4 The Law \& Practice of International Courts and Tribunals (2005), 421, 462 .

22 See, e.g., Michel Dubuisson, La Cour Internationale de Justice (1964), 65; Il Ro Suh, "Voting Behavior of National Judges in International Courts", ${ }_{3}$ American Journal of International Law (1969), 224, 230.

23 Hersch Lauterpacht, The Function of Law in the International Community (1933), 236-243.

24 Stephen Schwebel, "National Judges and Judges ad hoc of the International Court of Justice", 48 International \& Comparative Law Quarterly (1999), 889, 895-896.

25 Institut de Droit International, "Study of Amendments to be made in the Statute of the International Court of Justice", 45 Annuaire de l'Institut de Droit International (1954), 534; Nicolas Valticos, supra note 1, 11 .

26 Connie Peck and Roy S. Lee (eds.), Increasing the Effectiveness of the International Court of Justice: Proceedings of the ICJ/UNITAR Colloquium to celebrate the 5oth Anniversary of the Court (1997), 370, 378-379. 
are intellectually disposed to a legal reasoning broadly resembling that of the State with whom they have the closest connection, and that such judges will arrive at similar conclusions to the said States 'par affinité, parenté ou identité intellectuelle.' Accordingly, one can identify objectively an intellectual affinity of international judges with the policies of States, a wholly different argument than that of institutional control by States. ${ }^{27}$

Judges ad hoc are not thus to be identified with the interests of the appointing state. ${ }^{28}$ The fact that they are appointed by a state party to the dispute does not therefore in itself compromise their impartiality. ${ }^{29}$ In consequence, it is believed that they have a role and function within the Court, namely, to ensure that the arguments in favour of the appointing state have been fully appreciated.

This view has also been complemented by noting that it would be excessive to reduce (by means of the bonds to a state party to the dispute) the role and function of this kind of judge to a mere control of the analysis of the arguments by the Court. ${ }^{30}$ Consequently, it is pointed out that a judge ad hoc (when the latter is a national of the appointing state) may contribute in providing knowledge about the internal laws of that state ${ }^{31}$ and the appraisal of certain evidence from sources belonging to it. ${ }^{32}$ Similarly, he or she is expected

27 Gleider I. Hernández, "Impartiality and Bias at the International Court of Justice", 1 Cambridge Journal of International and Comparative Law (2012), 183, 199.

28 Nagendra Singh, The Role and Record of the International Court of Justice (1989), 192-193.

29 José Luis Jesus, "Judges ad hoc in the International Tribunal for the Law of the Sea", in Holger P. Hestermeyer et al. (eds.), 2 Coexistence, Cooperation and Solidarity: Liber Amicorum Rüdiger Wolfrum (2012), 1661, 1663.

$30 \quad$ Hubert Thierry, "Au Sujet du Juge ad hoc", in Julio A. Barberis et al. (eds.), Liber Amicorum "In Memoriam" of Judge Jose María Ruda (2000), 285, 287-288.

31 Pieter H.F. Bekker, "Diffusion of Law: The International Court of Justice as a court of transnational justice", in Rudolf Dolzer et al. (eds.), Making Transnational Law Work in the Global Economy: Essays in Honour of Detlev Vagts (2010), 417, 478; see, e.g., The "Enrica Lexie" Incident (Italy v. India), supra note 18. This view, however, has been vigorously criticised by persons such as Sir Elihu Lauterpacht. For him, this argument is not especially persuasive as it assumes two things that do not always happen. First, that the judge ad hoc is a national of the appointing state. Second, in certain occasions he or she is acquainted with the relevant domestic rules and therefore has knowledge that would be superior to the knowledge that other members of the court would gain after analysing the arguments of the parties. Cf. C. Peck and R. Lee (eds.), supra note 26, 375 .

32 Stephen Schwebel, "National Judges and Judges ad hoc", in René-Jean Dupuy (ed.), Mélanges en l'Honneur de Nicolas Valticos : Droit et justice (1999), 319, 328. 
to bring to the Court a perspective of the region with which the application deals, as well as a more detailed familiarity with that region's background. ${ }^{33}$ Case

\subsection{Participation of the Judge ad hoc when the Appointing Party is Absent from the Proceedings}

Throughout the discussions within the Committee of Jurists, it was not foreseen that a state party to the proceedings may appoint a judge ad hoc and then decide not to appear anymore (notwithstanding the reasons it may adduce for doing so). Nonetheless, if one takes into account that the appointment of the judge $a d$ hoc is a prerogative of states, as well as the fact that Article 35, paragraph 6, of the Rules of Court consecrates the rule that "when the reasons for the participation of a judge ad hoc are found no longer to exist, he shall cease to sit on the Bench", it might be considered that the non-appearance of the appointing state is to be regarded as one of the reasons to terminate the term of office of the judge ad hoc.

Several reasons militate, however, against this position. Therefore, it is necessary to refer to: (i) the position of the judge ad hoc with respect to other members of the Court; (ii) the manner in which Article 35, paragraph 6, of the Rules of Court should be interpreted; and (iii) the practice of the Court (in the sense of the construction and application of Article 53 of its Statute to this situation) in order to demonstrate that the non-appearance of the appointing state does not preclude the judge ad hoc from participating in the proceedings.

As noted by the Inter-American Court of Human Rights, a judge ad hoc is similar in nature to other judges and sits in an individual capacity; he or she does not sit as a representative of the appointing state, with a view of protecting the independence and impartiality of an international court of justice. ${ }^{34}$ Article 31, paragraph 6, of the Statute of the Court clearly indicates that a judge ad hoc shall take part in the decision on terms of complete equality with his or

33 Request for an Examination of the Situation in accordance with paragraph 63 of the Court's Judgment of 20 December 1974 in the Nuclear Tests (New Zealand v. France) case, Order, I.C.J. Reports 1995, (Dissenting Opinion, Judge ad hoc Sir Geoffrey Palmer), p. 420, para. 118. Case of the "White Van" (Paniagua Morales et al.) v. Guatemala, Order of 11 September 1995, para. 1. 
her colleagues. ${ }^{35}$ The differences between judges ad hoc and other members of the Court are therefore more formal than material, ${ }^{36}$ although judges ad hoc are judges for the occasion and not permanent judges. ${ }^{37}$ Consequently, the judge $a d$ hoc is legally and morally bound to act no less impartially than the rest of the members of the Court, ${ }^{38}$ just like the person to be appointed should possess the qualifications to be elected as a member of the Court. ${ }^{39}$ In consequence, he or she is prevented from serving in the case at hand only when a factor, ${ }^{40}$ amongst those referred to in Articles 17, 20 and 24 of the Statute of the Court, is not met. In any case, this is an aspect to be decided by the Court and not by the parties, in accordance with Article 35, paragraph 4, of the Rules of Court. In this regard, it is difficult to consider the non-appearance of the appointing state as a reason for the judge ad hoc to cease to sit on the bench.

Regarding Article 35, paragraph 6 of the Rules of Court, no practice exists concerning it and the purpose and scope of this provision is not clear. ${ }^{41} \mathrm{In}$ spite of these shortcomings, its scope and the meaning of the term "reasons" contained therein can be ascertained by reference to Article 31 of the Statute of the Court, which governs the appointment of judges ad hoc. Thus, when commenting on these provisions, Shabtai Rosenne noted that, despite nothing

35 This constituted, for instance, the reason why the Committee of Jurists decided not to allow judges voting against the majority to give the reasons for their dissents. It was considered that the dissenting opinion of a national judge - or judge ad hoc - would lead to a long opinion in favour of his or her country's position, in the event that country has lost its case. Consequently, as national judges - and judges ad hoc - were not to be given the possibility of making public their reasons for dissent, it would not be desirable for the rest of the judges to append their reasons when the former do not have such a possibility. Cf. Advisory Committee of Jurists, supra note 18, at 742-743.

36 For instance, Hubert Thierry has noted that “[l]e juge ad hoc, en effet, n'est pas tout à fait un juge comme les autres dès lors que ceux qui sont 'membres de la Cour' son élus pour neuf ans par l'Assemblée générale et le Conseil de Sécurité de l'onu, tandis que le juge ad hoc est désigné par l'une des parties pour siéger dans une affaire déterminée". Hubert Thierry, supra note 30, 285 .

37 Questions relating to the Obligation to Prosecute or Extradite (Belgium v. Senegal), Provisional Measures, Order, I.C.J. Reports 20og, (Judge ad hoc Sur, Separate Opinion), p. 201, para. 2.

38 Stephen Schwebel, supra note 24, 893 .

39 André Oraison, "Reflexions sur l'Institution du Juge ad hoc siégeant au Tribunal du Palais de la Paix en Séance Plénière ou en Chambre ad hoc", $3_{1}^{1}$ Revue Belgique de Droit International (1998), 271, 284.

$40 \quad$ Case of the "White Van", supra note 34, para. 3.

41 Juan José Quintana, Litigation at the International Court of Justice: Practice and Procedure (2015), 210. 
being said in the Statute of the Court or in its Rules concerning the duration of an appointment "one might presume that the appointment [of a judge $\mathrm{ad}$ hoc] continues until the final disposal of the case for which [he or she was] appointed."42 Similarly, his or her appointment for the said role is independent of the position taken by the appointing state with regard to the jurisdiction of the Court or the admissibility of the claim. ${ }^{43}$ Hence, the reason for his or her appointment is none other than the exercise of the right (of the state) to appoint him or her, as well as the exercise of his or her role and function (which will be referred to below) as a judge ad hoc. Consequently, the non-appearance of the appointing state cannot be regarded as a reason for making him or her cease to sit on the bench. These reasons should therefore be understood as referring to the termination of the proceedings, by his or her death, resignation or non-compliance with what is required by Articles 17, 20 and 24 of the Statute of the Court.

Lastly, it remains to refer to the practice of the Court in this connection by means of its position taken in the Corfu Channel case and the manner in which it applied Article 53 of its Statute to the said case.

In this regard, having participated in the preliminary objections and merits phases of the proceedings, Albania decided not to appear before the Court after the decision on the merits. It considered that the special agreement signed between itself and the United Kingdom did not allow the Court to fix the amount of compensation. ${ }^{44}$ Judge ad hoc Ečer took part in the decision of the Court and moreover appended a dissenting opinion to that decision. Consequently, the practice of the Court shows that a judge ad hoc is able to participate in the absence of the appointing party.

The reason for such a decision from the Court can be found in the manner in which it interpreted and applied Article 53 of its Statute to this situation. The Court explicitly indicated that, in the circumstances of the said case, Albania had failed to defend its case. ${ }^{45}$ Hence, and by treating the lack of appearance by the respondent in the proceedings as amounting to failing to defend its case, the Court acknowledged that no further consequences had arisen from the position taken by Albania. The state remained a party to the case ${ }^{46}$ despite

42 Shabtai Rosenne, "Article 31 of the Statute of the International Court of Justice revisited", in René-Jean Dupuy (ed.), Mélanges en l'Honneur de Nicolas Valticos : Droit et justice (1999), 301, 315.

43 Pieter Kooijmans, supra note 1, $53^{2}$.

44 The Corfu Channel Case, supra note 12, p. 246.

45 Ibid., p. 248.

46 Military and Paramilitary Activities in and against Nicaragua, supra note 13, p. 14, para. 28. 
some views to the contrary ${ }^{47}$ Moreover, as has been noted above, the application of Article 53 of the Statute does not amount to a sanction imposed on the non-appearing state. ${ }^{48}$ To accept the opposite view would be tantamount to considering that the judge ad hoc is a representative of the appointing state and would be in contradiction with the fact that the judge ad hoc is bound to exercise his powers impartially and independently. ${ }^{49}$ In consequence, the judge ad hoc, due to the solemn declaration he or she has made, is called to participate in the proceedings even in the absence of the appointing state.

\subsection{The Role and Function of the Judge ad hoc when the Appointing State is Absent from the Proceedings}

All of the aspects concerning the role and function of judges ad hoc that have been presented in Section 3 above (important as they are), seem to be somewhat put into question when the appointing state is absent from the proceedings. This is so, as the role and function of the judge ad hoc seem to be dependent on the active participation of the said state throughout the proceedings. In particular, the submission of (formal) written pleadings is fundamental for the exercise of the role and function of the judge ad hoc. Without (formal) arguments from the non-appearing state, the judge ad hoc seems unable to ensure that the arguments of the appointing party are fully appreciated by the Court during its deliberations. The same can be said concerning the evidence that emanates from the non-appearing state. The judge ad hoc would not be able to fulfil his or her role of appraising evidence belonging to sources from that state, since the weight of that evidence is to be assessed in the light of what is required to secure the proper administration of justice. Similarly, the fact that the judge ad hoc is in charge of providing knowledge about the internal laws of the state is also put into question, since the current practice shows that, today, it is not uncommon for a judge $a d$ hoc to be chosen from a state of a different nationality and even a different geographical group from that of the appointing state. ${ }^{50} \mathrm{He}$ or she does not therefore have the possibility to provide knowledge about the state party's internal laws.

\footnotetext{
47 Nuclear Tests (Australia v. France), Judgment, I.C.J. Reports 1974, (Separate Opinion, Judge Gros), p. 290, para. 25 .

48 See Section 4.2 below.

49 As the former judge of the International Tribunal for the Law of the Sea, José Luis Jesus noted in an academic article, "the fact that judges ad hoc are chosen by a State Party to a dispute does not in itself comprise their impartiality." Cf. Jose L. Jesus, supra note 29, 1663.

Shabtai Rosenne, supra note 42, 311 .
} 
It is in view of the above, and bearing in mind what has been concluded in the previous part of this section regarding the participation of the judge ad hoc when the appointing party is absent from the proceedings, that the question arises as to what are the role and function of the judge ad hoc in a situation of this kind.

In this regard, two aspects are relevant to provide an answer to this question. First, it is the usual practice of states not participating in the proceedings to file documents not amounting to formal pleadings and therefore not to be in a position to keep with the requirements of the Statute and Rules of Court. Similarly, it is the practice of the Court to take into account these informal documents for the determination of its decision. ${ }^{51}$ The judge ad hoc can therefore still perform the role and function for which he or she has been appointed.

Nonetheless, his or her role and function, as exercised when both parties to the dispute are present before the Court, seem to be limited by the distinctive characteristics of the function of the Court in non-appearance situations. Two aspects are worth noting in this regard. First, that in non-appearance situations the Court has been careful with regard to treating these documents like regular pleadings. ${ }^{52}$ Second, that the task of the Court, in situations of nonappearance, is to satisfy itself that the claim is well founded in fact and law. In this sense, the role and function of the judge ad hoc need to be adjusted to these distinctive characteristics; otherwise, he or she might be considered as a representative of the appointing state and therefore someone who is not acting independently and impartially. In other words, when ensuring that any relevant argument in favour of the appointing state is fully appreciated by the Court, or when providing knowledge about the internal laws of the state or appraising evidence belonging to sources from the appointing state, the judge ad hoc should not act in any manner inconsistent with the duty of the Court to satisfy itself that the applicant state's claim is well founded in fact and law. He or she can only therefore bring to the attention of the Court an argument in favour of the appointing state or appraise evidence belonging to sources from the appointing state when it is in line with the proper administration of justice (as required in situations of non-appearance), and it can show that the applicant's claim is not sound in law or when the facts on which that claim is based are not supported by convincing evidence. ${ }^{53}$

\footnotetext{
$51 \quad$ Fisheries Jurisdiction, supra note 16, p. 9.

52 Juan José Quintana, supra note 41, 1100.

53 Military and Paramilitary Activities, supra note 13, p. 24, para. 29.
} 
Second, one cannot lose sight of the fact that the differences between other members of the Court and a judge ad hoc are more formal than material..$^{54}$ All of the judges (irrespective of how they have been appointed) are expected to exercise their duties impartially and independently. ${ }^{55}$ Hence, no real difference exists with respect to other members of the Court, in view of the need that all members of the Court (including judges ad hoc) should fulfil all the conditions required by the Court's Statute. The discussion on the role and function of judges ad hoc has therefore arisen due to the difference regarding the manner in which they are appointed. In other words, their role and function are the same role and function as those of the rest of the members of the Court. Consequently, the role and function of judges ad hoc that were mentioned in the section above are to be considered as a complement to the role and function that all judges are called to exercise.

The judge ad hoc is therefore not deprived of his "basic" role and function when the appointing state decides not to participate in the proceedings. He is also called to exercise the role and function of the rest of the members of the Court, by virtue of having the duty to act impartially and independently and by being a member of the Court. ${ }^{56}$ In consequence, and in spite of the limits that the non-appearance of his appointing state may create, he still has to fulfil the role and function of his office as a judge of the Court.

\section{5}

\section{Conclusion}

Both non-appearance of the respondent state and the appointment of judges ad hoc are a not-uncommon occurrence in the history of the Court. ${ }^{57}$ Moreover, both institutions have been amply analysed in the academic literature. Regarding the former, it has been focused on analysing the manner in which the Court should decide a case in the absence of one of the parties to the proceedings. As for the latter, one of the recurrent topics that has been ad-

54 Cf. Il Ro Suh, supra note 22, 231.

55 Cf. Manfred Lachs, "Some Reflections on the Nationality of Judges of the International Court of Justice", 4 Pace Yearbook of International Law (1992), 49, 61-68.

56 On the role and function of international judges, see, e.g., Sir Elihu Lauterpacht, "The Role of the International Judge", in Bruylant (eds.), Le Procés International: Liber Amicorum Jean-Pierre Cot (2010), 185-192; José E. Alvarez, "What are International Judges for? The Main Functions of International Adjudication", in Cesare Romano et al. (eds.), The Oxford Handbook of International Adjudication (2013), 158, 158-178.

57 Cf. James G. Devaney, Fact-Finding before the International Court of Justice (2016), 118. 
dressed is the role and function of judges ad hoc. Nonetheless, that situation and the institution have always been analysed separately. So far, no analysis has been made with regard to the role and function of the judge ad hoc in the absence of the appointing state. This is a question that is relevant when a state fails to defend its case, after having appointed a judge ad hoc.

This article has attempted to address the said question in the light of the distinctive characteristics that non-appearance presents as to the procedure to be followed by the Court. It has been submitted that, due to the distinctive characteristics of proceedings in cases of non-appearance, the role and function of the judge ad hoc experience a variation when compared to the role and function exercised when the appointing state appears before the Court throughout the proceedings. This is a necessary variation in view of the need for the Court to preserve the sound administration of justice.

This conclusion is based on both the Court's case law on non-appearance and the existing academic literature on the role and function of judges ad hoc. Consequently, and given the scarcity of cases in which this situation has occurred, this conclusion is subject to be revisited in the future when (even if it is not desirable) a state that has appointed a judge $a d$ hoc fails to defend its case. 